$\mathrm{A} \int_{\text {aiss }} \underset{0976-2 \cdot 2 \times x}{\mathrm{H}}$

Received : 04.06.2014

Revised : 11.10 .2014

Accepted : 25.10.2014

Members of the Research Forum

Associated Authors:

Department of Vegetable Science, GB

Pant University of Agriculture and

Technology, PANTNAGAR

(UTTARAKHAND) INDIA

Author for correspondence

\section{RASHID KHAN}

Department of Horticulture, Maharana Pratap University of Agriculture and

Technology, UDAIPUR (RAJASTHAN)

INDIA

Email :rsdptn7@gmail.com
THE ASIAN JOURNAL OF HORTICULTURE

Volume 9 | Issue 2 |Dec., 2014 | 356-359

Visit us -www.researchjournal.co.in
$A$.

$\mathrm{S}$

RESEARCH PAPER

DOI : $10.15740 / \mathrm{HAS} / \mathrm{TAJH} / 9.2 / 356-359$

\title{
Germplasm characterization in eggplant (Solanum melongena L.)
}

\section{RASHID KHAN AND Y.V. SINGH ${ }^{1}$}

ABSTRACT : Brinjal (Solanum melongena L.) is an important solanaceous vegetable in many countries of Asia and Africa. Assessment of genetic resources is the starting point of any crop improvement programme. In the present study, 192 accessions of eggplant were evaluated for ten quantitative and eleven qualitative characters. A significant difference was observed in all characters. The wide regional variations for plant, flower and fruit descriptors revealed enough scope for improvement of yield characters by selection. The genetic differences among the genotypes are potentially relevant to breeding programmes in that the variability created through hybridization of the contrasting forms could be exploited.

KEY WORDS : Germplasm, Eggplant, Solanum melongena, Characterization

HOW TO CITE THIS ARTICLE : Khan, Rashid and Singh, Y.V. (2014). Germplasm characterization in eggplant (Solanum melongena L.). Asian J. Hort., 9(2) : 356-359. 